\title{
Carbonation-Induced Mineralogical Changes in Coal Mining Waste Blended Cement Pastes and Their Influence on Mechanical and Microporosity Properties
}

\author{
Moisés Frías ${ }^{1, *}$ (i) , Raquel Vigil de la Villa ${ }^{2}$, Rosario García ${ }^{3}$ (D), Olga Rodríguez ${ }^{1}$, \\ Lucía Fernández-Carrasco $^{3}$ (iD) and Sagrario Martínez-Ramírez ${ }^{4}$ (i) \\ 1 Eduardo Torroja Institute for Construction Sciences (IETcc-CSIC), 28033 Madrid, Spain; \\ olgarodriguez@cenim.csic.es \\ 2 Department of Geology and Geochemistry, Universidad Autónoma de Madrid, CSIC-UAM Associated \\ Unit (Unidad Asociada CSIC-UAM), 28049 Madrid, Spain; raquel.vigil@uam.es \\ 3 Architectural Technology Department, Universitat Politècnica de Catalunya-Barcelona TECH, \\ 08028 Barcelona, Spain; rosario.garcia@uam.es (R.G.); lucia.fernandez@upc.edu (L.F.-C.) \\ 4 Institute for the Structure of Matter (IEM-CSIC), 28006 Madrid, Spain; sagrario@iem.cfmac.csic.es \\ * Correspondence: mfrias@ietcc.csic.es; Tel.: 34-91-302-0440
}

Received: 12 February 2018; Accepted: 17 April 2018; Published: 20 April 2018

\begin{abstract}
The worldwide pursuit of new eco-efficient pozzolans is ongoing. Kaolinite-based waste is an eco-friendly source of recycled metakaolinite, a highly pozzolanic product. In this study, a blended cement paste containing $20 \%$ activated coal waste (ACW) was exposed to a $100 \% \mathrm{CO}_{2}$ atmosphere at $65 \%$ RH for 7 days. The variations in its phase composition and strength were studied and compared to an OPC control. Both pastes were cured for 28 days prior to the carbonation test. Reaction kinetics were assessed using XRD, SEM/EDX, TG/DTG, FT-IR, Micro-Raman spectroscopy, pore solution $\mathrm{pH}$ and the cumulative carbonated fraction. The blended cement carbonated $68 \%$ faster than the control. While portlandite carbonation was the main reaction in both cements, decalcification was also observed (more intensely in the $20 \%$ ACW paste) in other hydraulic calcium phases (C-S-H gel, monocarboaluminate $\left(\mathrm{C}_{4} \mathrm{AcH}_{12}\right)$, ettringite and tetracalcium aluminate $\left(\mathrm{C}_{4} \mathrm{AH}_{13}\right)$. The end product of this reaction was calcium carbonate, mainly in the form of calcite, although traces of aragonite and amorphous carbonate were also detected. Compressive strength values rose with accelerated carbonation time and pore size reduction in both cement pastes.
\end{abstract}

Keywords: coal mining waste; blended cements; accelerated carbonation; mineralogy; properties

\section{Introduction}

Ordinary Portland cements (OPCs) are known to be scantly resistant to aggressive agents such as chlorides, sea water, sulfates and $\mathrm{CO}_{2}$, which, when reacting with the hydrated phases in cement, induce expansion, cracking, strength loss, a decline in stiffness, and disintegration [1-3]. Active additions are known to raise the durability of Portland cements. These additions, characterised by their ability to convert portlandite into hydraulic phases similar to the ones obtained during Portland cement hydration, improve the microstructure and performance of blended cements [4-13].

According to Younsi et al. [14], the mechanism governing cement matrix carbonation is affected by a number of properties of the material as well as by the surrounding environment. In particular, carbonation is governed by $\mathrm{CO}_{2}$ diffusivity in concrete and the chemical reactions between $\mathrm{CO}_{2}$ and carbonatable phases. Carbon dioxide dissolves in water to form $\mathrm{H}_{2} \mathrm{CO}_{3}$, which reacts with the $\mathrm{Ca}^{2+}$ 
sourced primarily from portlandite dissolution and C-S-H gel decalcification $[15,16]$. To date most studies on cementitious material carbonation have focused on the effect of permeability, the hydration chemistry of carbonated structural concrete and changes in porosity [17], or on the use of cellulose fibres as reinforcement in composite manufacture to enhance durability [18].

General studies on the effect of $\mathrm{CO}_{2}$ on cements have shown that OPCs exhibit higher carbonation resistance than pozzolan-bearing blended cements [19]. Castellote et al. [20] observed that the main effect of carbonation on concrete is the reduction of the $\mathrm{pH}$ in its pore solution, which in turn induces reinforcing steel depassivation and corrosion. They found that the carbonation rate in cement depends on the $\mathrm{w} / \mathrm{c}$ ratio, composition, pore structure, curing conditions, internal moisture, hydrated phase solubility and kinetic or thermodynamic factors [21]. Goñi et al. [22] reported that the alkaline content in two OPCs (with equivalent $\mathrm{Na}_{2} \mathrm{O}$ values of 1.03 and $0.43 \%$ ) had a scant effect on carbonation kinetics in accelerated carbonation testing. $\mathrm{Xu}$ et al. [23] observed similar concrete behaviour in a $100 \%$ $\mathrm{CO}_{2}$ atmosphere.

The transformation of a kaolinite based industrial waste into a metakaolinite base pozzolan, is one of the main lines of research worldwide, due to its environmental and social interest. This study forms part of a broader research project on the development of blended cements made with activated material from coal mining waste with a view to obtaining innovative eco-efficient cements. Earlier studies [24-30] showed that it is scientifically and technically feasible to convert this inert pollutant waste into a supplementary cementitious material. Their findings have charted a promising alternative route for obtaining recycled metakaolinite, a pozzolan listed in the existing legislation on cement [31].

The dearth of research on the durability of cements bearing activated coal mining waste prompted this study on the behaviour of blended cement pastes ( 0 and $20 \%$ ACW replacement) during accelerated carbonation in a $100 \% \mathrm{CO}_{2}$ and $65 \% \mathrm{RH}$ atmosphere. The variations in the mineralogical phases during carbonation and reaction kinetics, determined by $\mathrm{CaCO}_{3}$ content and pore solution $\mathrm{pH}$, are reported.

\section{Materials and Methods}

\subsection{Materials}

The coal mining waste used was supplied by Hullera Vasco-Leonesa, Sociedad Anónima, miners operating out of Santa Lucía in the Spanish province of León. This waste was activated in a laboratory furnace for $2 \mathrm{~h}$ at $600{ }^{\circ} \mathrm{C}$, the optimal temperature from the standpoint of both pozzolanicity and economic and energy efficiency $[27,28]$. The material obtained was substantially more reactive with portlandite than other types of inorganic waste [32]. The activated waste (ACW) was ground with an agate mortar and pestle to a size of under $70 \mu \mathrm{m}$, i.e., similar to the size of the particles in the OPC Spanish commercial cement used (classified as CEM I $52.5 \mathrm{~N}$ ) [31]. The Bogue [33] mineral composition of the OPC cement was: $C_{3} S=41.04 \% ; C_{2} S=30.00 \% ; C_{3} A=11.54 \%$; and $C_{4} A F=9.70 \%$.

The chemical compositions of the two starting materials are given in Table 1.

Table 1. Chemical composition of starting materials.

\begin{tabular}{|c|c|c|c|c|c|c|c|c|c|c|c|c|c|}
\hline \multicolumn{14}{|c|}{ Majority Oxides (\%) } \\
\hline Sample & $\mathrm{SiO}_{2}$ & $\mathrm{Al}_{2} \mathrm{O}_{3}$ & $\mathrm{Fe}_{2} \mathrm{O}_{3}$ & $\mathrm{CaO}$ & $\mathrm{K}_{2} \mathrm{O}$ & $\mathrm{TiO}_{2}$ & $\mathrm{MgO}$ & $\mathrm{SO}_{3}$ & $\mathrm{Na}_{2} \mathrm{O}$ & $\mathrm{P}_{2} \mathrm{O}_{5}$ & $\mathrm{MnO}$ & & DI \\
\hline OPC & 21.22 & 6.39 & 3.19 & 61.38 & 1.67 & 0.17 & 1.97 & 0.42 & 0.87 & 0.20 & 0.04 & & 49 \\
\hline $\mathrm{ACW}$ & 52.63 & 25.29 & 4.64 & 4.20 & 3.09 & 1.17 & 0.77 & 0.27 & 0.17 & 0.14 & 0.08 & & 09 \\
\hline \multicolumn{14}{|c|}{ Minor Elements (ppm) } \\
\hline Sample & $\mathrm{Cu}$ & $\mathbf{N i}$ & $\mathrm{Cr}$ & $\mathbf{V}$ & $\mathrm{Zn}$ & $\mathrm{Pb}$ & $\mathrm{Cl}$ & Co & F & Sr & $\mathbf{Y}$ & Mo & As \\
\hline OPC & 117 & 76 & 149 & 54 & 36 & 14 & 237 & 19 & 929 & 392 & 6 & - & - \\
\hline $\mathrm{ACW}$ & - & 65 & 210 & 162 & 25 & 4 & 46 & 24 & - & - & - & 21 & 2 \\
\hline
\end{tabular}




\subsection{Paste Preparation}

The blended cement was prepared by blending $20 \%$ ACW with the OPC for $20 \mathrm{~min}$ in a mechanical mixer at $100 \mathrm{rpm}$. The OPC and the $20 \% \mathrm{ACW}$-containing cement were mixed with demineralised water at a w/c ratio of 0.5 , after which the resulting pastes were poured into $1 \times 1 \times 6 \mathrm{~cm}^{3}$ prismatic moulds, vibration-compacted and stored in a curing chamber at $100 \% \mathrm{RH}$ for 1 day, further to the methodology described by Koch-Steinegeer [34]. The samples were subsequently removed from the moulds and cured by soaking in demineralised water for 28 days at $19^{\circ} \mathrm{C}$. This curing procedure was followed by 15 days storage at $65 \%$ RH. Accelerated carbonation was conducted in a semi-dynamic, $100 \% \mathrm{CO}_{2}$ atmosphere (injecting the gas into the chamber at $12 \mathrm{~h}$ intervals to ensure saturation) at $20 \pm 1{ }^{\circ} \mathrm{C}$ for 7 days. After each exposure period, cement samples were vacuum-dried for 2 days (at $320 \mathrm{mbar}$ ) prior to conducting the porosimetry test. For the other analyses, the samples were immersed in acetone for 1 day and then vacuum-dried for another $24 \mathrm{~h}$.

\subsection{Methods and Test Techniques}

Chemical composition was determined on a Philips PW 1404 X-ray fluorescence spectrometer fitted with a Sc-Mo X-ray tube (Philips, Amsterdam, The Netherlands).

The carbonation front was visualized with phenolphthalein as described in Spanish standards [35]. Carbonation depth was measured in terms of declining alkalinity, using a $1 \%$ phenolphthalein solution dissolved in $70 \%$ ethyl alcohol as a $\mathrm{pH}$ indicator. This indicator is colourless for values of under 8.0, pinkish-purple for values from 8.0 to 9.8 and reddish-purple for values of over 9.8. As the pore solution could not be collected directly due to the low relative humidity prevailing during carbonation and the small amount of sample available, it was simulated by dissolving $0.5 \mathrm{~g}$ of the ground bulk sample in $3 \mathrm{~mL}$ of de-ionised water. The solid was subsequently filtered and the liquid was analysed for $\mathrm{pH}$ in the $0,1,3,4$ and 7 days carbonated OPC and $20 \%$ ACW specimens.

The mineralogical composition of the bulk samples was determined by random powder X-ray diffraction (XRD) on a Siemens D-5000 X-ray diffractometer fitted with a $\mathrm{Cu}$ anode (Siemens, Munich, Germany). The operating conditions were $30 \mathrm{~mA}$ and $40 \mathrm{kV}$ with a $2 \mathrm{~mm}$ divergence and a $0.6 \mathrm{~mm}$ receiving slit. Qualitative interpretation of the powder diffraction spectra was found with X'Pert High Score Plus 4.1 software running with database PDF-2 (release 2008, International Centre for Diffraction Data, Newtown Square, PA, USA). Rietveld-refined semi-quantification of the phases was performed with Match 3.5.2 software, using rutile as the internal standard to quantify the amorphous phase. The $\chi^{2}$ (weighted profile $\mathrm{R}$ factor) values fluctuated from 5 to $20[36,37]$.

Cement paste microstructure was analysed under an Inspect FEI Company scanning electron microscope (FEI Company, Hillsboro, OR, USA), equipped with an energy dispersive X-ray analyser (W source, DX4i analyser and $\mathrm{Si} / \mathrm{Li}$ detector).

The sections were scanned sequentially from the rim to the centre using a $552 \mu \mathrm{m}$ high, $470 \mu \mathrm{m}$ wide window. Around 40 fields at a radiation exposure time were needed for the transverse scan of half of the section, equivalent to analysing a section around $18.8 \mathrm{~mm}$ wide. All the samples were gold-sputtered to enhance image resolution and high vacuum-scanned on a back scattering electron detector (BSED) at a resolution of $4.0 \mathrm{~nm}$ at $30 \mathrm{kV}$ and on an Everhart-Thornley (ETD) secondary electron detector at resolutions of $3.0 \mathrm{~nm}$ at $30 \mathrm{kV}$ and $10 \mathrm{~nm}$ at $3 \mathrm{kV}$. The accelerating voltage was $26 \mathrm{kV}$ to $30 \mathrm{kV}$ and the working height and distance, $10 \mathrm{~nm}$. The samples were analysed on an Oxford Instruments INA Energy 200 energy dispersive X-ray spectrometer (EDS) operating at $20 \mathrm{kV}$. The analyser was pre-calibrated using internal standards to improve the ZAF correction procedure.

Thermogravimetric readings (TG/DTG) were taken on a Stanton STA 781 analyser using $12 \mathrm{mg}$ to $16 \mathrm{mg}$ powder samples, heated at a rate of $10^{\circ} \mathrm{C} / \mathrm{min}$ in an $\mathrm{N}_{2}$ atmosphere.

A Nicolet 6700 FT-IR spectroscope was used for the Fourier transform infrared analyses, conducted in a spectral region of $400 \mathrm{~cm}^{-1}$ to $4000 \mathrm{~cm}^{-1}$. Specimens were prepared by pressing $1.3 \mathrm{mg}$ of sample into $300 \mathrm{mg}$ of $\mathrm{KBr}$. 
Dispersive micro-Raman spectra were recorded on a Renishaw Invia system fitted with a Leica confocal Raman microscope and electrically cooled CCD camera. The excitation source was a Renishaw Nd: YAG 532-nm laser. The samples were analysed with a $5 \mathrm{~mW}$ laser beam. The spectral resolution was set at $4 \mathrm{~cm}^{-1}$. Spectra were recorded in triplicate using a $50 \times$ objective lens over a wavenumber range of $4000 \mathrm{~cm}^{-1}$ to $100 \mathrm{~cm}^{-1}$. The exposure time was $10 \mathrm{~s}$ and each spectrum was accumulated 10 times at ten separate points.

A set of five $1 \times 1 \times 6 \mathrm{~cm}^{3}$ prismatic specimens for each type of cement paste $(0$ or $20 \% \mathrm{ACW})$ and curing age was tested to failure to determine compressive strength on an Ibertex Autotest 200/105 W frame fitted with an adapter for this type of specimens.

Mercury intrusion porosimetry was used to ascertain the effect of ACW on the mean pore size of blended cements. The analyses were performed $1 \times 1 \times 1 \mathrm{~cm}^{3}$ samples using a Micromeritics 9500 pore sizer.

\section{Results and Discussion}

\subsection{Carbonation Depth}

Figure 1 shows that the carbonation front was more sharply defined and deeper in the $20 \%$ ACW than in the OPC paste. Replacing $20 \%$ of the cement with ACW increased the carbonation rate after the first $24 \mathrm{~h}$ of exposure. The blended cement carbonated for 7 days was completely colourless, while the OPC paste had pink edges and a reddish-purple core with uneven borders.

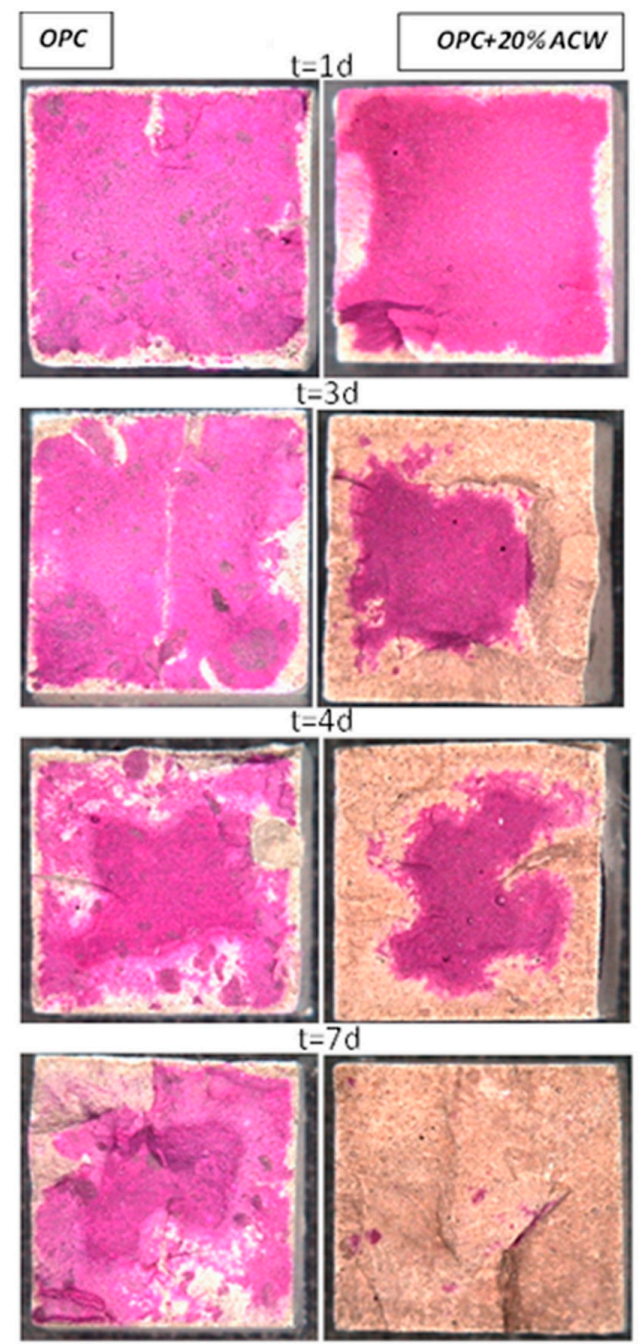

Figure 1. Variation in carbonation front with exposure time. 
The depth of the carbonation front plotted against the square root of time in Figure 2 shows the differences in behaviour between the two cements. The variation in the OPC paste was linear during the 7 days of the trial, with carbonation depth rising slightly (with $\mathrm{R}^{2}$ values of nearly 0.99 in both cases, denoting a high correlation between the two variables). The carbonation front for the $20 \%$ ACW paste, in contrast, fit a second-degree polynomial curve, clearly indicating that after the first day, penetration depth grew rapidly with exposure time due to the presence of the thermally activated waste. That finding was attributable to the reduction in the amount of carbonatable material, primarily from portlandite and C-S-H gels, with the addition of the replacement.

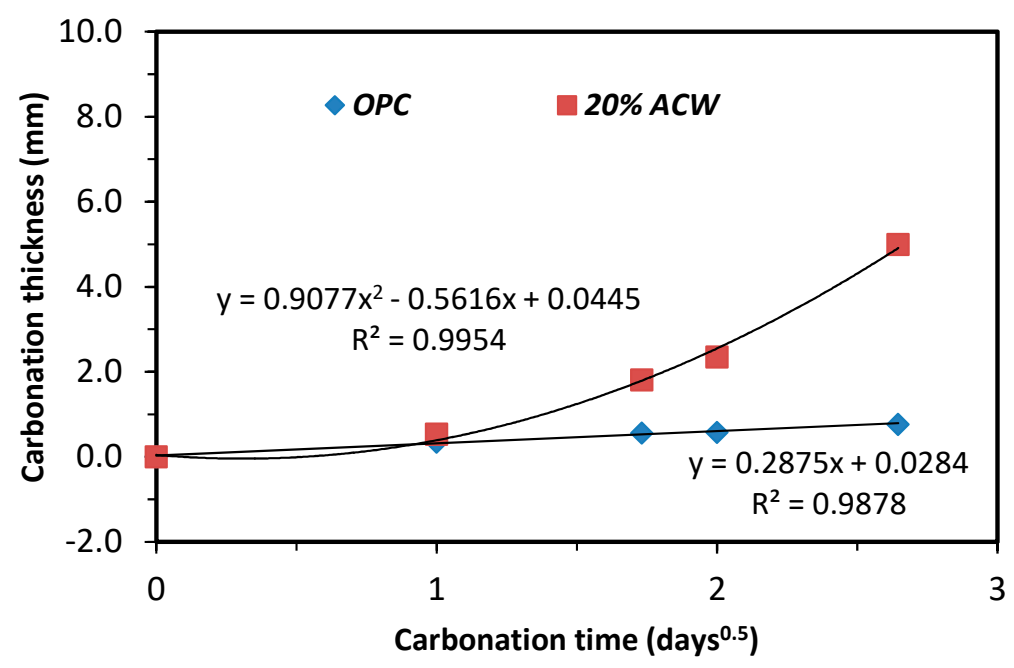

Figure 2. Depth of carbonation front vs. square root of exposure time.

The differences in the carbonation rates for the two materials can be deduced from the slope of the regression lines. These values, at 0.91 and 0.29 for the $20 \%$ ACW and OPC pastes, respectively, denoted a $78 \%$ higher rate in the former than in the latter. The inference is that the addition of pozzolans (alone or blended) had an adverse effect on the carbonation rate. This pattern is wholly consistent with other authors' reports on the effect of carbonation on ternary blended cements (fly ash, fly ash-metakaolin, fly ash + activated paper sludge) [38-40].

The scientific explanation generally put forward for the lower resistance to carbonation in pozzolan-bearing blended cements is two-pronged. Firstly, the higher alkaline content in these additions would lower portlandite solubility [22]. However, the slight difference between the $\mathrm{Na}_{2} \mathrm{O}$ equivalent $\left(\mathrm{Na}_{2} \mathrm{O}+0.658 \mathrm{~K}_{2} \mathrm{O}\right)$ recorded for the $20 \%$ blended cement, namely 2.02, and the 1.96 observed for the OPC paste (Table 1) would not appear to justify such a significant divide in their respective carbonation rates.

Secondly, researchers such as Van Balen and Van Gemert [41] reported a relationship with the volume of carbonatable material (calcium hydrate phases).

\subsection{Simulated Pore Solution $\mathrm{pH}$}

The difference in the $\mathrm{pH}$ variation patterns in the two cements is shown in Figure 3. The values declined across the 7 days of $\mathrm{CO}_{2}$ exposure, more steeply in the $20 \%$ ACW paste, where it dropped from 12.6 to 11.2 , whereas in the OPC paste it dipped by only 0.3 points, primarily after the first $24 \mathrm{~h}$. Due to the brief duration of the carbonation test (7 days), the pattern observed differed from the findings for ternary Portland cement (with $21 \%$ activated paper sludge + fly ash) reported by Frías and Goñi [40], where the $\mathrm{pH}$ fell to values of under 10. Two plateaus were identified in this decline, the first, at 12.5, attributed to the dissolution of portlandite, with the precipitation of calcite, and C-S-H gel with a high $\mathrm{Ca} / \mathrm{Si}$ ratio; the second, at 11 to 11.2, possibly related to the $\mathrm{pH}$ equilibrium between $\mathrm{AFt}$ (ettringite) and AFm (monosulfoaluminate). These same authors reported that carbonation-induced 
neutralisation of alkalinity was the root cause of C-S-H gel decalcification, a finding likewise consistent with the decline in pore solution $\mathrm{pH}$ observed here (from 12.5 to 11.2).

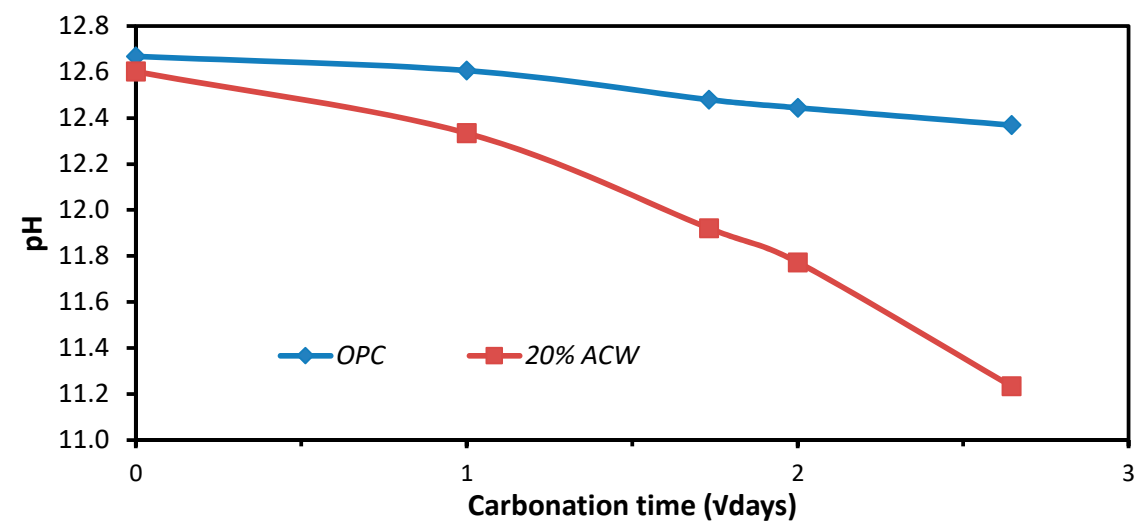

Figure 3. $\mathrm{pH}$ vs. square root of exposure time.

The present findings showed that the $\mathrm{pH}$ decreased more sharply in the $20 \% \mathrm{ACW}$ than in the ordinary Portland cement, despite their similar $\mathrm{NaO}_{2}$ equivalents (1.97 and 2.02, respectively), apparently suggesting that the C-S-H gel generated (by the pozzolanic reaction) in the blended cement had a lower $\mathrm{Ca} / \mathrm{Si}$ ratio than the gel in the OPC paste [42]. The higher carbonation rate in blended cements in general and in the $20 \%$ ACW paste studied in particular, would be attributable to such circumstances (Figure 1).

\subsection{Variation in Mineralogical Phases}

\subsubsection{XRD and SEM Findings}

The mineralogical composition of the crystalline phases of the starting $\mathrm{CW}$ and $\mathrm{ACW}$ materials is shown in Table 2.

Table 2. Rietveld-refined mineralogical composition of crystalline phases.

\begin{tabular}{ccc}
\hline Mineral (\%) & CW & ACW \\
\hline Mica & 25 & 20 \\
Quartz & 29 & 35 \\
Kaolinite & 14 & - \\
Calcite & 15 & 10 \\
C $_{4}$ AF & - & - \\
Bassanite & - & - \\
$\mathrm{C}_{3} \mathrm{~A}$ & - & - \\
$\mathrm{C}_{3} \mathrm{~S}$ & - & - \\
$\mathrm{C}_{2} \mathrm{~S}$ & - & - \\
Amorphous M & 17 & 35 \\
$\mathrm{X}^{2}$ & 5.7 & 6.9 \\
Total & 100 & 100 \\
\hline \multicolumn{2}{c}{$\mathrm{X}^{2}:$ Weighted profile R factor. }
\end{tabular}

The crystalline mineralogical phases observed in the 28 days cured $(t=0)$ OPC paste shown in Figure 4 included alite $\left(\mathrm{C}_{3} \mathrm{~S}, \mathrm{~A}\right)$, belite $\left(\mathrm{C}_{2} \mathrm{~S}, \mathrm{~B}\right)$, calcite $(\mathrm{Ca})$, portlandite $(\mathrm{P})$, ettringite $(\mathrm{E})$, tetracalcium aluminate hydrate $\left(\mathrm{C}_{4} \mathrm{AH}_{13}, \mathrm{Al}\right)$, and monocarboaluminate hydrate $\left(\mathrm{C}_{4} \mathrm{AcH}_{12}, \mathrm{C}\right)$. 


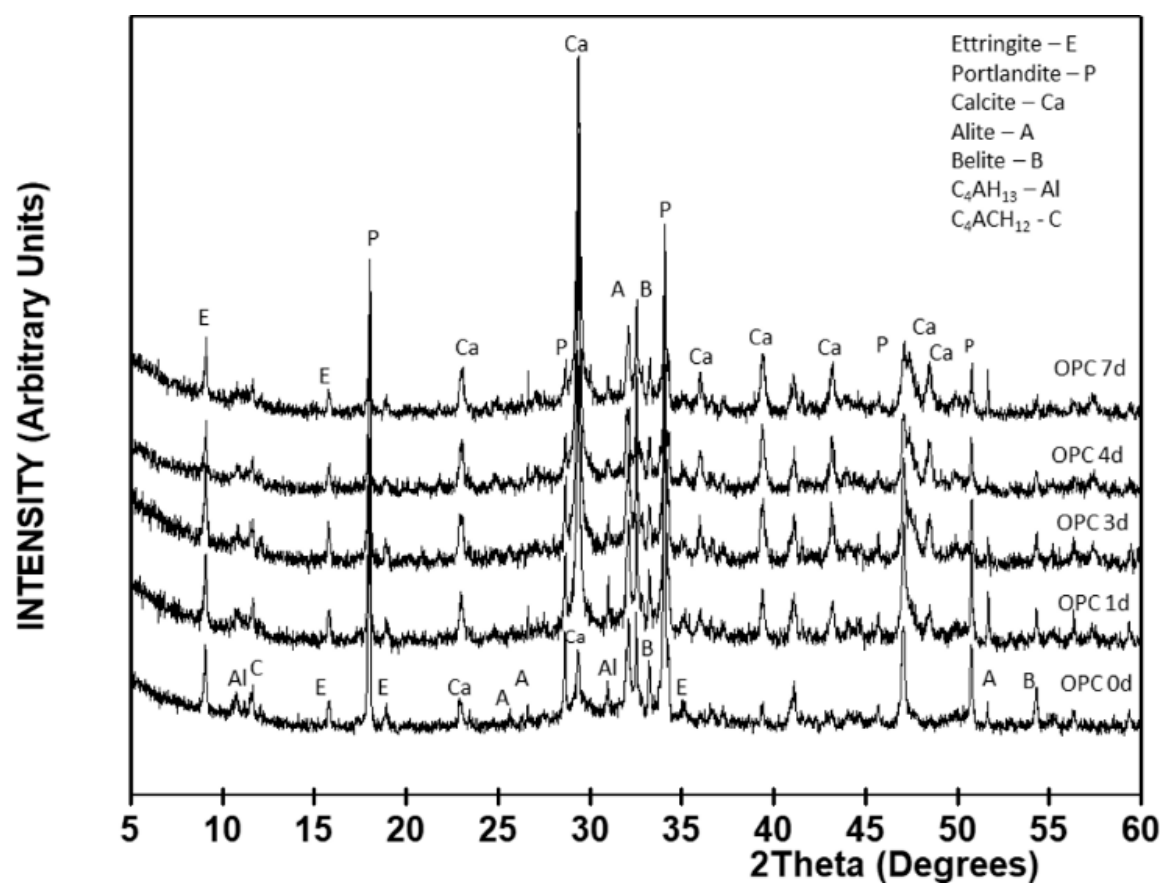

Figure 4. XRD spectra for 0, 1, 3, 4 and 7 days carbonated ordinary Portland cements (OPC) paste.

The semi-quantitative XRD findings (Table 3) for the crystalline phases in the OPC paste denoted a clear change in the mineralogical phases from the third day of carbonation. In the first $24 \mathrm{~h}$ of accelerated carbonation, the content of all the phases except calcite declined and remained flat until the end of day 3. At that time calcite, the main mineralogical phase, accounted for $56 \%$ of the total, portlandite for $14 \%$ and $\mathrm{C}_{2} \mathrm{~S}$ for $11 \%$. From the fourth to the seventh day, none of the crystalline phases was affected by $\mathrm{CO}_{2}$, an indication that the carbonation front had stabilized in the cement matrix.

Table 3. Rietveld-refined mineralogical composition of 28 days cured OPC paste by time of exposure to accelerated carbonation.

\begin{tabular}{cccccc}
\hline Mineral (\%) & OPC & 1 Day & 3 Days & 4 Days & 7 Days \\
\hline $\mathrm{C}_{3} \mathrm{~S}$ & 1 & - & - & - & - \\
$\mathrm{C}_{2} \mathrm{~S}$ & 17 & 15 & 11 & 11 & 11 \\
$\mathrm{C}_{4} \mathrm{AcH}_{12}$ & 14 & 10 & 9 & 9 & 9 \\
$\mathrm{C}_{4} \mathrm{AH}_{13}$ & 7 & 5 & 2 & 2 & 2 \\
$\mathrm{C}_{3} \mathrm{~A} .3 \mathrm{SO}_{4} \mathrm{Ca} \cdot \mathrm{H}_{32}$ & 15 & 13 & 8 & 8 & 8 \\
$\mathrm{Ca}(\mathrm{OH})_{2}$ & 25 & 9 & 8 & 8 & 8 \\
$\mathrm{CaCO}$ & 11 & 42 & 56 & 56 & 56 \\
$\mathrm{Amorphous} \mathrm{M}$ & 10 & 6 & 6 & 6 & 6 \\
$\mathrm{X}^{2}$ & 7.6 & 6.8 & 7.3 & 7.3 & 7.3 \\
Total & 100 & 100 & 100 & 100 & 100 \\
\hline
\end{tabular}

With the addition of $20 \%$ ACW to the OPC (Figure 5 and Table 4 ), the intensity patterns varied from the findings for the control in all the reflections except in the line attributed to quartz, which appeared in the $20 \%$ ACW only. Excepting calcite and quartz, content declined gradually in all the crystalline mineralogical phases to practically disappear after 7 days of exposure. At $84 \%$ of the total 7 day crystalline phases, calcite content was 59\% greater in the blended cement paste than in the OPC paste. This finding clearly shows that the presence of $20 \% \mathrm{ACW}$ hastened the decomposition of these hydrated phases, as they had been identified in the OPC. 


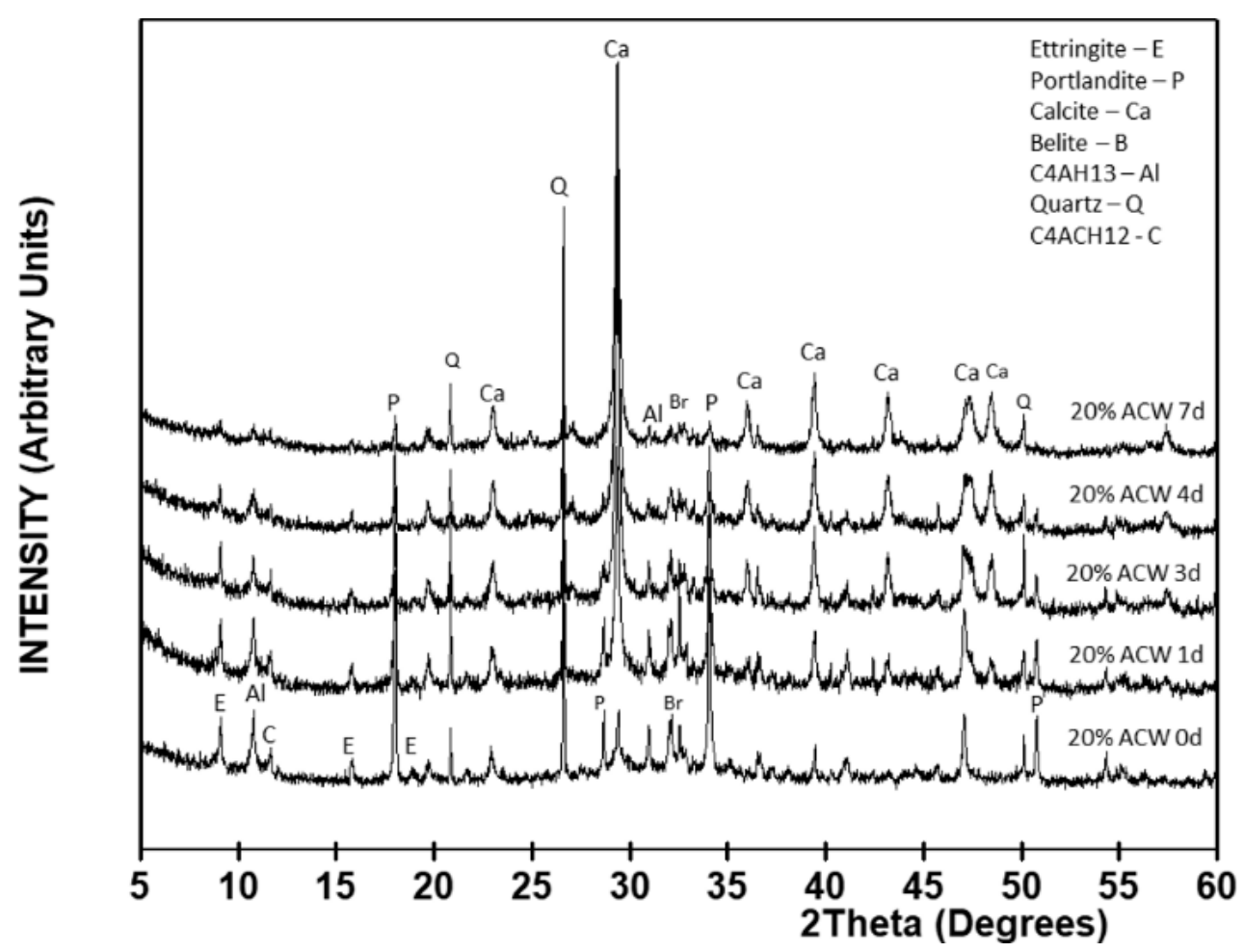

Figure 5. XRD spectra for 0, 1,3, 4 and 7 days carbonated 20\% ACW.

Table 4. Rietveld-refined mineralogical composition of 28 days cured $20 \%$ ACW by time of exposure to accelerated carbonation.

\begin{tabular}{cccccc}
\hline Mineral (\%) & $\mathbf{2 0} \%$ ACW & 1 Day & 3 Days & 4 Days & 7 Days \\
\hline $\mathrm{C}_{2} \mathrm{~S}$ & 7 & 7 & 3 & 2 & - \\
$\mathrm{Mica}$ & 3 & - & - & - & - \\
$\mathrm{SiO}_{2}$ & 9 & 9 & 9 & 9 & 9 \\
$\mathrm{C}_{4} \mathrm{AcH}_{12}$ & 11 & 3 & 2 & - & - \\
$\mathrm{C}_{4} \mathrm{AH}_{13}$ & 20 & 9 & 4 & 3 & - \\
$\mathrm{C}_{3} \mathrm{~A} .3 \mathrm{SO}_{4} \mathrm{Ca} . \mathrm{H}_{32}$ & 9 & 10 & 4 & 2 & 1 \\
$\mathrm{Ca}(\mathrm{OH})_{2}$ & 23 & 5 & 1 & - & - \\
$\mathrm{CaCO}$ & 9 & 45 & 65 & 73 & 81 \\
Amorphous & 9 & 12 & 12 & 11 & 9 \\
$\mathrm{X}^{2}$ & 4.5 & 6.8 & 7.2 & 8.4 & 6.3 \\
Total & 100 & 100 & 100 & 100 & 100 \\
\hline
\end{tabular}

These findings are consistent with reports by Pizzol et al. [43] for hybrid fibre cement composites exposed to accelerated carbonation for $10 \mathrm{~h}$ at $60^{\circ} \mathrm{C}$ and $90 \% \mathrm{RH}$, in which no crystalline ettringite, monosulfate or monocarboaluminate was identified in the carbonated composite.

The present findings show that the addition of $20 \%$ ACW to OPC hastens carbonation. They attest not only to portlandite carbonation but also to the decalcification of calcium-bearing phases such as ettringite, monocarboaluminate, tetracalcium aluminate and even dicalcium silicate $\left(\mathrm{C}_{2} \mathrm{~S}\right)$ as a result of their reaction with $\mathrm{CO}_{2}$.

SEM analysis of the OPC pastes carbonated for 4 days revealed the formation of incipient calcite rhombohedral crystals along the edges of the ettringite prisms and (primarily) in the voids and cavities in the C-S-H gels (Figure 6). The EDX chemical microanalysis findings for the mineralogical phases are given in Table 5. 


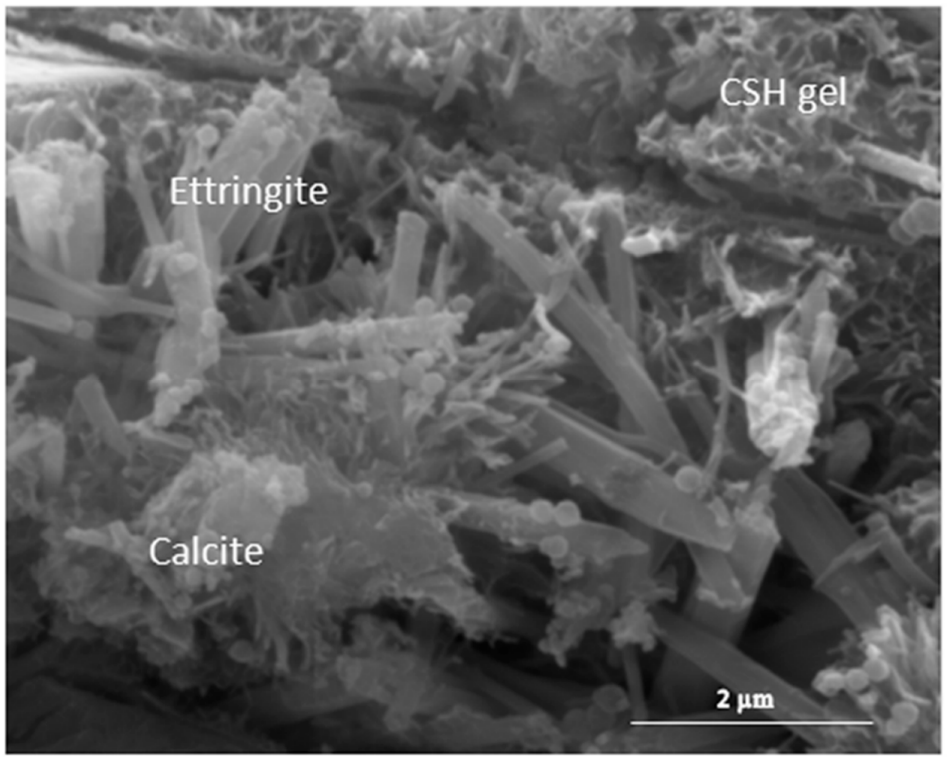

Figure 6. Morphology of compounds in 4 days carbonated OPC paste.

Table 5. EDX chemical analysis of the hydrated phases.

\begin{tabular}{cccc}
\hline Oxide (\%) & C-S-H Gel & Ettringite & $\mathrm{CaCO}_{3}$ \\
\hline $\mathrm{Na}_{2} \mathrm{O}$ & $0.94 \pm 0.27$ & - & - \\
$\mathrm{MgO}$ & $1.88 \pm 0.52$ & - & - \\
$\mathrm{Al}_{2} \mathrm{O}_{3}$ & $3.97 \pm 0.89$ & $25.76 \pm 2.68$ & - \\
$\mathrm{SiO}_{2}$ & $31.54 \pm 1.27$ & $5.35 \pm 1.39$ & - \\
$\mathrm{SO}_{3}$ & $1.10 \pm 0.55$ & $10.07 \pm 0.96$ & - \\
$\mathrm{CaO}$ & $59.65 \pm 2.31$ & $58.82 \pm 2.12$ & 100 \\
$\mathrm{Fe}_{2} \mathrm{O}_{3}$ & $0.92 \pm 0.24$ & - & - \\
\hline
\end{tabular}

The $20 \%$ replacement favoured the generation of calcite rhombohedral crystals, which formed massively on the surface and in the voids in the material carbonated for 4 days, although the crystal size was smaller in the latter (Figure 7).

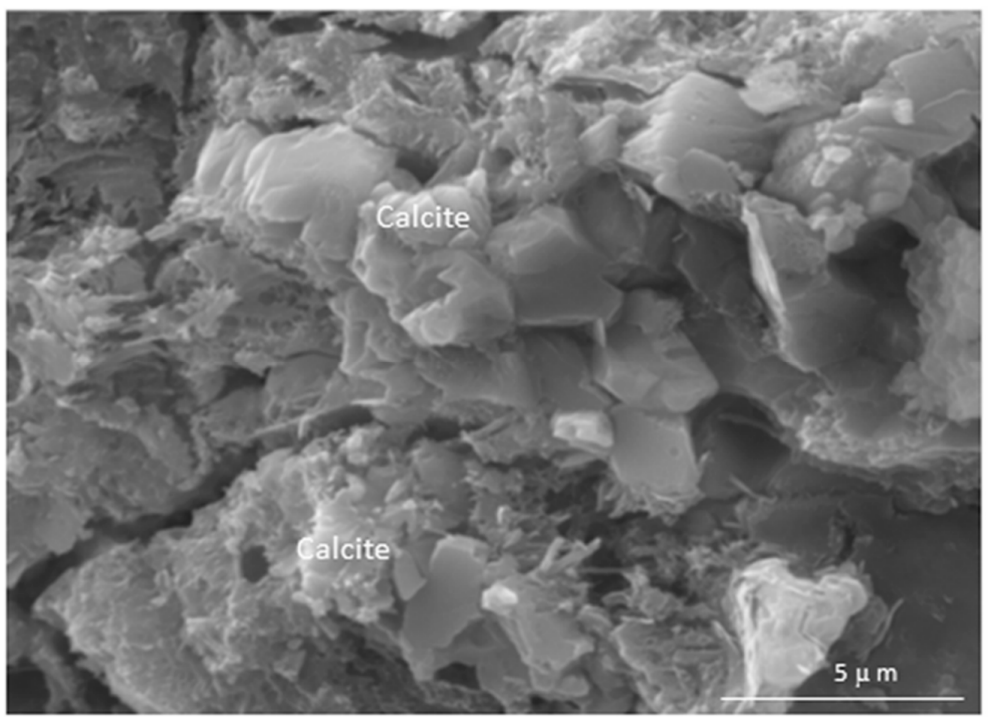

Figure 7. Morphology of compounds in 4 days carbonated 20\% ACW. 
Very small calcium and calcite deposits were observed on the surface in the non-carbonated area of the 7 days OPC paste, while calcite crystals less than $2 \mu \mathrm{m}$ in size clustered on both the surface and in the voids in the carbonated zone. The $20 \%$ replacement favoured the formation of calcite rhombi that accumulated profusely on the surface of the carbonated area of the specimen.

\subsubsection{TG/DTG Analysis}

The DTG analyses conducted identified hydrated phase decomposition during the 7 days accelerated carbonation trial. The following processes were clearly observed in both the OPC and the $20 \%$ ACW pastes: ettringite (Ett), C-S-H gel and aluminate hydrate $\left(\mathrm{C}_{4} \mathrm{AH}_{13}\right)$ dehydroxylation, which respectively induced peaks at around $51{ }^{\circ} \mathrm{C}, 92{ }^{\circ} \mathrm{C}$ and $145{ }^{\circ} \mathrm{C}$ in a broad band spanning from $40{ }^{\circ} \mathrm{C}$ to $200^{\circ} \mathrm{C}$; and the loss of interlayer water in hydrated monocarboaluminate $\left(\mathrm{C}_{4} \mathrm{AcH}_{12}\right)$, generating a weak band at $255{ }^{\circ} \mathrm{C}$. The intensities of the main decomposition bands for the C-S- $\mathrm{H}$ gels, ettringite and $\mathrm{C}_{4} \mathrm{AH}_{13}$ declined with carbonation time, more notably in the $20 \% \mathrm{ACW}$ blended cement. That finding ratified the effect of carbonation (decalcification) not only on portlandite, but also on other hydrated phases $[14,44,45]$. The intensity of the peak centred over $435^{\circ} \mathrm{C}$ generated by portlandite decomposition declined as decarbonation advanced, with only traces of the mineral appearing in the 7 days $20 \%$ ACW paste. A band at $650{ }^{\circ} \mathrm{C}$ to $750{ }^{\circ} \mathrm{C}$, peaking at $733^{\circ} \mathrm{C}$ and increasing in intensity with time, was attributed to carbonate decomposition.

Whilst both carbonated cements underwent gradual weight loss between $450{ }^{\circ} \mathrm{C}$ and $650{ }^{\circ} \mathrm{C}$, this loss was much more significant in the cement containing the $20 \%$ replacement. Further to findings reported by Black et al. [16], this observation might be associated with the formation of an amorphous calcium carbonate hydrate generated by the decalcification of the calcium hydrate phases, primarily C-S-H gels (the majority phase in cement hydration).

Table 6 gives the $\mathrm{Ca}(\mathrm{OH})_{2}, \mathrm{CaCO}_{3}$, cumulative fraction carbonated (CFC) and chemically combined water contents calculated from the weight loss detected in the TG analyses (of the residue). The CFC was estimated by dividing the respective carbonate content (expressed as $\mathrm{CaO}$ ) by the $\mathrm{CaO}$ in the anhydrous cement and the pozzolan [40]. The plot of this parameter against the square root of time (up to 7 days) proved to be linear (Figure 8). Based on the slopes of these lines, the 20\% ACW cement carbonated at a $78 \%$ higher rate than the OPC paste, concurring with the trend illustrated in Figure 2.

Table 6. Thermogravimetric findings on compounds in cement (\%).

\begin{tabular}{cccccc}
\hline Cement & Time (Days) & $\mathbf{C a ( O H})_{2}$ & $\mathbf{C a C O}_{3}$ & $\begin{array}{c}\text { Cumulative Fraction } \\
\text { Carbonated (CFC) }\end{array}$ & Comb. Water \\
\hline \multirow{3}{*}{ OPC } & 0 & 26.34 & 9.40 & 0.09 & 20.51 \\
& 1 & 16.00 & 26.37 & 0.24 & 19.67 \\
& 3 & 14.40 & 34.73 & 0.32 & 20.31 \\
& 4 & 13.86 & 43.11 & 0.39 & 20.06 \\
$20 \% \mathrm{ACW}$ & 7 & 12.44 & 43.79 & 0.40 & 19.82 \\
\hline & 1 & 15.75 & 9.33 & 0.10 & 21.04 \\
& 3 & 13.69 & 24.76 & 0.28 & 18.97 \\
& 4 & 11.14 & 42.41 & 0.48 & 18.09 \\
& 7 & 6.26 & 47.59 & 0.53 & 18.34 \\
\hline
\end{tabular}




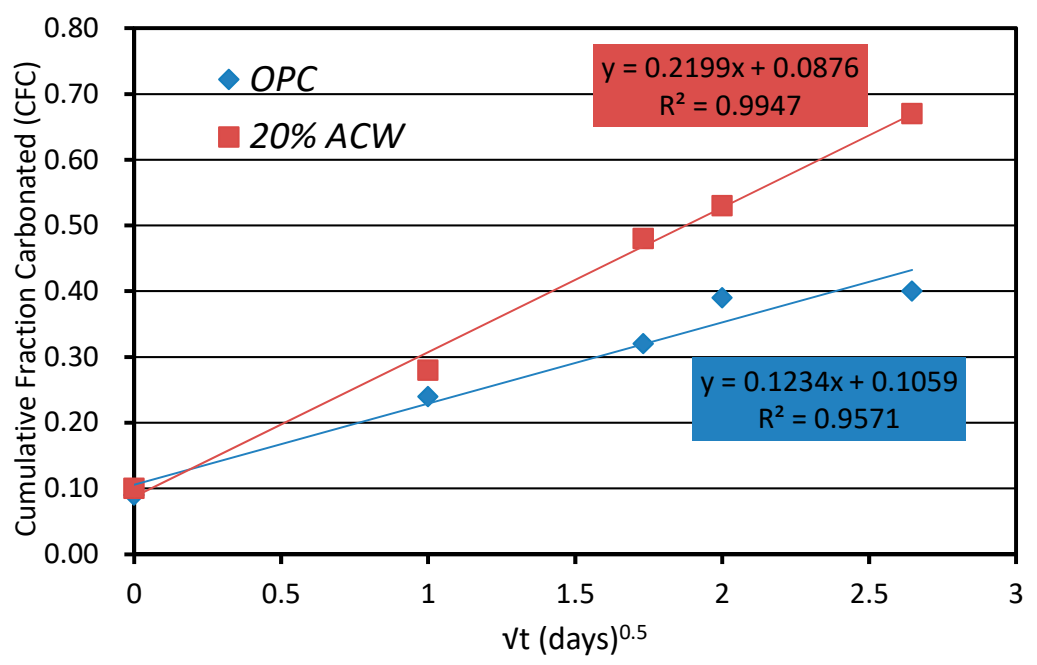

Figure 8. Cumulative fraction carbonated (CFC) content vs. square root of time.

\subsubsection{FT-IR and Micro-Raman Findings}

The FT-IR spectrum for the non-carbonated OPC specimen exhibited a sharply defined absorption band at $3644 \mathrm{~cm}^{-1}$, denoting the presence of portlandite and/or ettringite; a shoulder at $3520 \mathrm{~cm}^{-1}$, the region corresponding to $\mathrm{OH}$ vibrations in aluminates; and a band at $3440 \mathrm{~cm}^{-1}$ associated with $\mathrm{OH}$ vibrations in the C-S-H gel. At lower frequencies, an incipient absorption band near $1420 \mathrm{~cm}^{-1}$ was attributable to carbonates. The sulfate bands at $1115 \mathrm{~cm}^{-1}(\vee \mathrm{S}-\mathrm{O})$ and the Si-O vibration bands at around $975 \mathrm{~cm}^{-1}$ were typical of hydrated OPC paste. The band assigned to portlandite was present through the seventh day of hydration, despite the progressive rise in the intensity of the bands attributed to carbonates (compare to DTG results in Table 5). The FT-IR spectra for the two cement pastes are shown in Figure 9 by time of exposure to $\mathrm{CO}_{2}$.
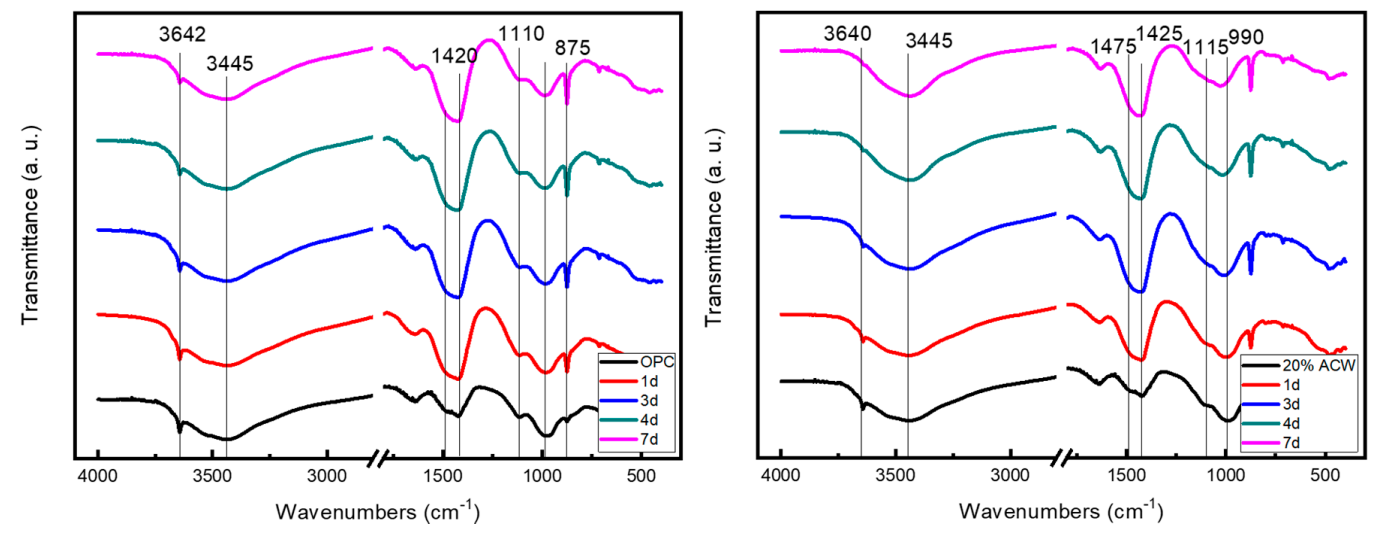

Figure 9. FT-IR spectra by exposure time for OPC (left) and 20\% ACW (right) pastes.

The $\mathrm{O}-\mathrm{H}$ bands attributable to portlandite and/or ettringite on the spectrum for the cured, non-carbonated $20 \%$ ACW cement were less intense than the analogous bands on the spectrum for OPC paste at $\mathrm{t}=0$ (which is consistent with the DTG results: Table 6). The S-O vibration-induced absorption band was broader and located at a lower frequency $\left(1100 \mathrm{~cm}^{-1}\right)$ on the $20 \%$ ACW than on the OPC paste spectrum. In contrast, the Si-O group absorption band appeared at a higher frequency, around $990 \mathrm{~cm}^{-1}$. This finding may be an indication of C-S-H gel decalcification [46].

The absorption band attributable to the $\mathrm{OH}$ present in portlandite and ettringite was less intense on FT-IR spectra for the 1 day OPC and $20 \%$ ACW carbonated samples and in general declined proportionally with carbonation time. 
The intensity of the bands at around $3520 \mathrm{~cm}^{-1}$ (sh) and $3440 \mathrm{~cm}^{-1}$ also waned with carbonation time. At lower frequencies, a very intense band at around $1420 \mathrm{~cm}^{-1}$ generated by $\mathrm{CO}_{3}{ }^{2-}$ groups denoted the presence of calcium carbonate, primarily as calcite, although a shoulder at $1470 \mathrm{~cm}^{-1}$ attested to the existence of aragonite. The absorption bands at around $875 \mathrm{~cm}^{-1}$, assigned to calcite, and $850 \mathrm{~cm}^{-1}$, to aragonite, supported this interpretation.

The effect of $\mathrm{CO}_{2}$ on the $20 \%$ ACW paste was less straightforward. The $\mathrm{OH}$ absorption band at $3644 \mathrm{~cm}^{-1}$ dropped significantly with carbonation time, disappearing altogether from spectrum on day 7. Band intensity at $3520\left(\mathrm{~cm}^{-1}\right)(\mathrm{sh})$ and $3440 \mathrm{~cm}^{-1}$ also declined with carbonation time; the shoulder, specifically, was absent from the 4 days spectrum.

As in the OPC samples, intense absorption bands generated by carbonated compounds appeared on the first day of carbonation. Their position $\left(1420 \mathrm{~cm}^{-1}\right)$ was indicative of calcite, an inference supported by the existence of a band at $875 \mathrm{~cm}^{-1}$. Shoulders at $1845 \mathrm{~cm}^{-1}$ and $850 \mathrm{~cm}^{-1}$ denoted the presence of small amounts of aragonite.

The absorption bands at $1100 \mathrm{~cm}^{-1}(\vee \mathrm{Si}-\mathrm{O})$ and $990 \mathrm{~cm}^{-1}$ (Si-O) clearly varied with carbonation time, respectively shifting to lower $\left(1080 \mathrm{~cm}^{-1}\right)$ and higher $\left(1030 \mathrm{~cm}^{-1}\right)$ frequencies and declining in intensity.

By way of summary, the FT-IR spectra showed that carbonation induced a decline in the portlandite and ettringite bands, an effect that was more visible in the $20 \%$ ACW paste. They also confirmed that calcite was the majority carbonation product. That finding was consistent with the micro-Raman results, which identified only the $\mathrm{CaCO}_{3}$ vibration band $\left(v 1\right.$ at $\left.1084 \mathrm{~cm}^{-1}\right)$ from calcite and/or aragonite and none of the other phases detected with XRD, such as carboaluminates. Due to the intensity of sample fluorescence, no C-S-H gel signals were observed on these spectra (Figure 10).
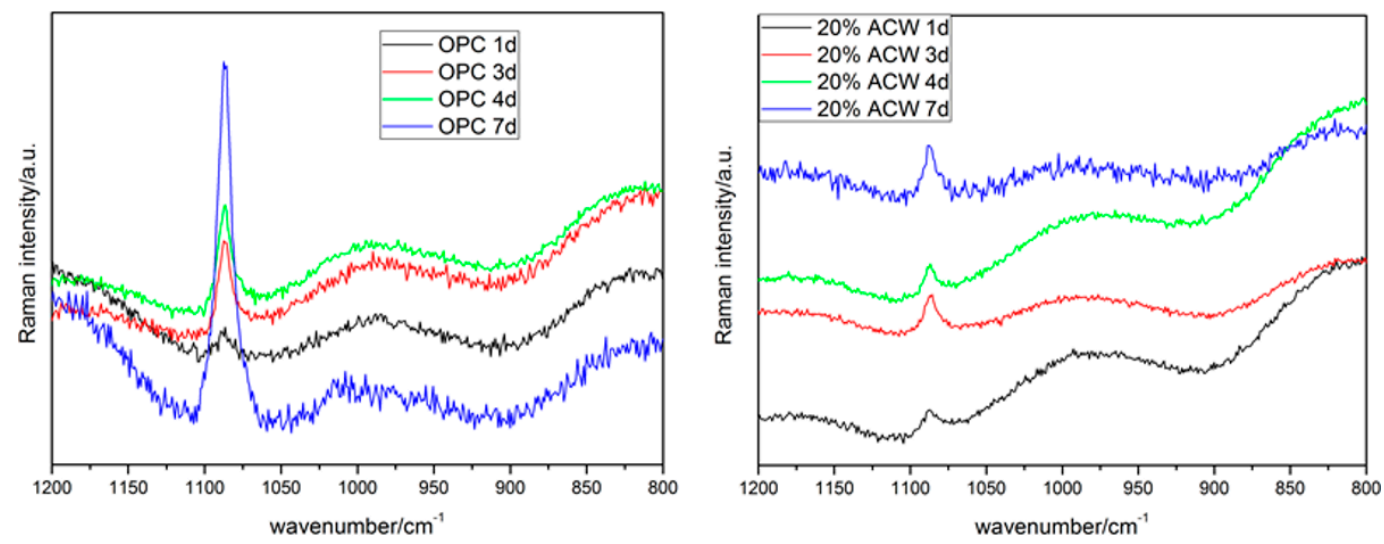

Figure 10. Raman spectra by exposure time for OPC (left) and 20\% ACW (right) pastes.

\subsection{Mechanical Strength and Microporosity}

The data in Table 7 denote the fluctuation in cement paste compressive strength. Strength rose with exposure time to $\mathrm{CO}_{2}$ in both the control and the experimental pastes, although their behaviour patterns differed. After 1 day of exposure, the two cements exhibited similar strength values, whereas strength was greater in the 3 days 20\% ACW blended cement than in the OPC paste. At longer carbonation times, the contrary was observed; strength was lower in the blended cement paste than in the OPC paste.

Table 7. Compressive strength (MPa) in 0-7 days carbonated cement pastes.

\begin{tabular}{cccccc}
\hline & 0 Day & 1 Day & 3 Days & 4 Days & 7 Days \\
\hline OPC & $52.4(1.1)$ & $53.5(4.55)$ & $55(3.6)$ & $70.8(5.1)$ & $85.2(2.9)$ \\
$20 \% \mathrm{ACW}$ & $50.6(1.5)$ & $52.3(3.8)$ & $65.6(4.4)$ & $66.4(3.5)$ & $77.2(5.0)$ \\
\hline
\end{tabular}


The abundance of calcite as the majority reaction product in accelerated carbonation had a heavy impact on mechanical behaviour and microporosity, as shown in Figure 11 where the carbonate content is plotted against compressive strength. Strength in the $20 \% \mathrm{ACW}$ cement rose linearly with increasing carbonate content, whereas the OPC paste followed an exponential pattern, with strength climbing steeply at carbonate percentages of over 35\%. The correlation between the two variables was high for both materials, with $\mathrm{R}^{2}$ values of 0.99 for ACW and 0.79 for OPC.

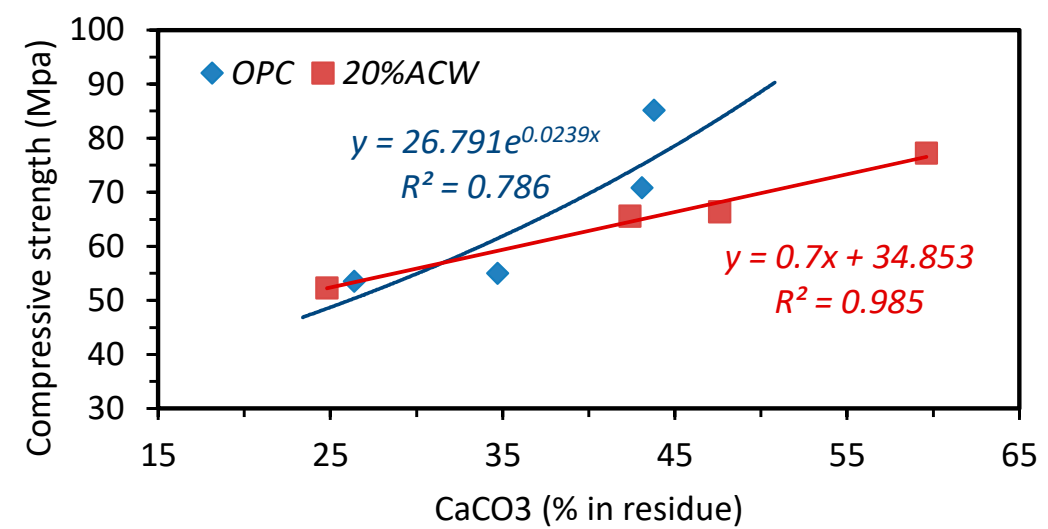

Figure 11. Carbonate content vs. compressive strength.

The increases in strength would be explained by the decline in total porosity (Table 8), which was steeper for the blended paste, and by the drop in the mean pore size ( $4 \mathrm{~V} / \mathrm{A})$ observed in mercury porosimetry tests: from $0.32 \mu \mathrm{m}$ at $\mathrm{t}=0$ day to $0.018 \mu \mathrm{m}$ at $\mathrm{t}=7$ days in OPC paste and from $0.025 \mu \mathrm{m}$ at $\mathrm{t}=0$ day to $0.020 \mu \mathrm{m}$ at $\mathrm{t}=7$ days in $20 \% \mathrm{ACW}$.

Table 8. Total porosity (\%) in OPC and $20 \%$ ACW pastes by carbonation age.

\begin{tabular}{cccccc}
\hline & 0 Day & 1 Day & 3 Days & 4 Days & 7 Days \\
\hline OPC & 21.2 & 17.18 & 15.17 & 14.25 & 12.48 \\
$20 \% \mathrm{ACW}$ & 23.22 & 18.33 & 16.94 & 14.55 & 12.84 \\
\hline
\end{tabular}

Those findings are related to pore network refinement in the carbonated cement pastes which, as the density curves in Figure 12 show, had no adverse effect on strength.

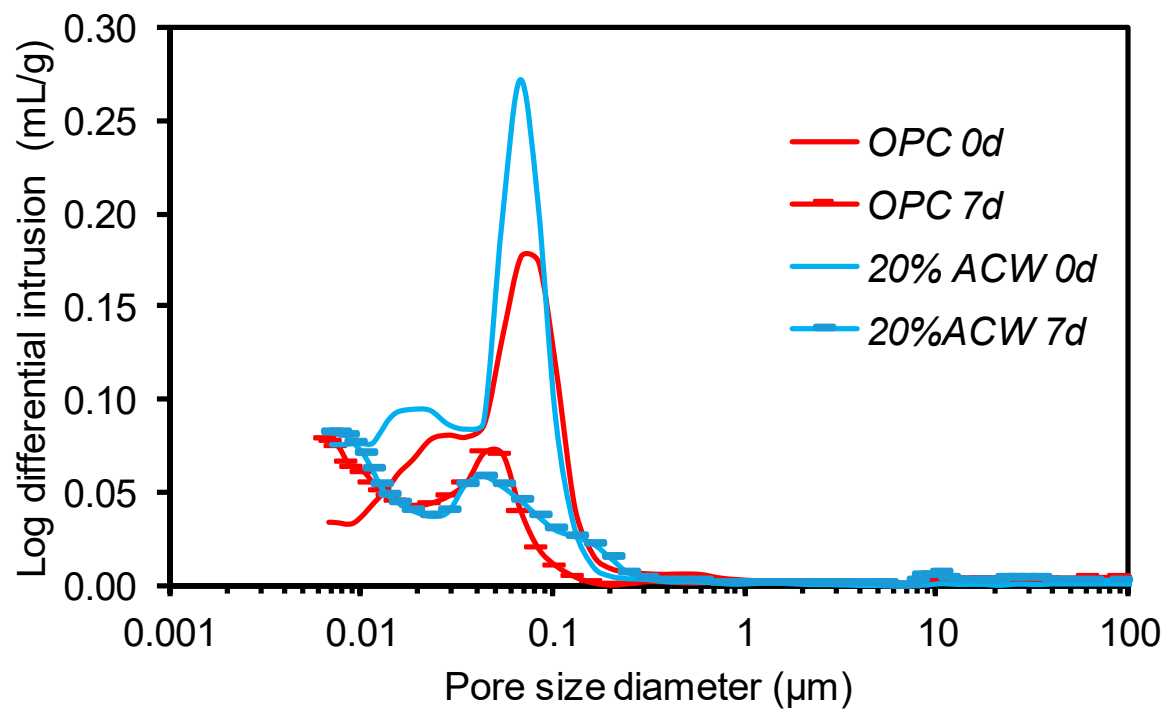

Figure 12. Density curves by exposure time. 


\section{Conclusions}

The conclusions drawn from the experimental results are as follows:

1. The results showed that after 7 days of accelerated carbonation the $20 \%$ ACW cement paste $\mathrm{pH}$ was 11.2, whereas the OPC pastes exhibited a large non-carbonated core $(\mathrm{pH}=12.5)$. The $20 \%$ blended pastes carbonated faster than the control.

2. Carbonation lowered the $\mathrm{pH}$ of the simulated pore solution, with values on day 7 of 11.2 in $20 \%$ ACW and 12.4 in OPC pastes, although neither dipped below the $\mathrm{pH}$ that induces depassivation in reinforcing steel $(\mathrm{pH}<10)$.

3. Calcite was the only carbonated crystalline phase detected by XRD, which identified no vaterite or aragonite, typically observed in natural carbonation processes. Traces of aragonite and amorphous phase were detected with FT-IR, however.

4. XRD semi-quantitative analysis showed that the inclusion of $20 \%$ activated coal waste in OPC paste hastened decalcification in the hydrated calcium phases identified (some as traces only) after the first $24 \mathrm{~h}$ of exposure to accelerated carbonation $\left(100 \% \mathrm{CO}_{2}\right)$.

5. Calcite, the final (7 days) majority product of carbonation in both cements, had a $50 \%$ higher content in the $20 \%$ ACW than in OPC pastes. These findings were confirmed by FT-IR and micro-Raman analysis.

6. The variation in DTG values with exposure time attested to portlandite decalcification while also denoting less intense decalcification in C-S-H gels and $\mathrm{C}_{4} \mathrm{AH}_{13}$.

7. Accelerated carbonation induced a rise in compressive strength and pore size refinement in both cement pastes. Strength values in the $20 \%$ ACW cement pastes rose linearly with increasing carbonate content, whereas the OPC paste followed an exponential pattern.

Acknowledgments: This research was funded by the Spanish Ministry of Economy and Competitiveness (Project Refs. MAT2012-37005-CO3-01/02/03) and MINECO/FEDER (BIA2015-65558-C3-1/2/3-R). The authors wish to thank the Sociedad Anónima Hullera Vasco-Leonesa (León, Spain), Sika (Madrid, Spain) and the Spanish Cement Institute (IECA) for their support in this research.

Author Contributions: Raquel Vigil and Rosario García analysed the XRD and SEM data; Olga Rodríguez performed the experiments; Lucía Fernández analysed the FT-IR data; Sagrario Martínez analysed the TG/DTA data; Moisés Frías designed the study and wrote the paper.

Conflicts of Interest: The authors declare no conflict of interest.

\section{References}

1. Dong, B.; Qieu, Q.; Gu, Z.; Xiang, J.; Huang, C.; Fang, Y.; Xing, F.; Liu, W. Charactarization of carbonation behaviour of fly ash blended cement materials by the electrochemical impedance spectroscopy. Cem. Concr. Compos. 2016, 65, 118-127. [CrossRef]

2. Mehta, P.K. Mechanism of sulfate attack on Portland cement Concrete-Another look. Cem. Concr. Res. 1983, 13, 401-406. [CrossRef]

3. Medina, G.; Sáez del Bosuqe, I.F.; Frías, M.; Sánchez de Rojas, M.I.; Medina, C. Granite quarry waste as a future eco-efficient supplementary cementititous materials: Scientific and technical considerations. J. Clean. Prod. 2017, 148, 467-476. [CrossRef]

4. Frías, M.; Goñi, S.; García, R.; Vigil, R. Seawater effect on durability of ternary cements. Synergy of chloride and sulphate ions. Compos. Part B Eng. 2013, 46, 173-178. [CrossRef]

5. Bahurudeen, A.; Kanraj, D.; Gokul, V.; Santhanam, M. Performance Evaluation of sugarcane bagasse ash blended cement in concrete. Cem. Concr. Res. 2015, 59, 77-88. [CrossRef]

6. Fausto, P.; Chastre, C.; Numes, A. Carbonation service life modelling of RC structures for concrte with Portland and blended cements. Cem. Concr. Compos. 2013, 37, 171-184.

7. Andrade, C.; Bujak, R. Effect of some mineral additions to Portland cement on reinforcement corrosion. Cem. Concr. Res. 2013, 53, 59-67. [CrossRef]

8. Ahmed, D.A.; Ragai, S.M. Retardation effect and corrosion detection of blended cement pastes. Hous. Build. Natl. Res. Cent. 2013, 9, 22-26. [CrossRef] 
9. Medina, C.; Sáez del Bosque, I.F.; Asensio, E.; Frías, M.; Sánchez de Rojas, M.I. New additions for eco-efficient cement design. Impact on calorimetric behaviour and comparison of test methods. Mater. Struct. 2016, 49, 4595-4607. [CrossRef]

10. Vegas, I.; Gaitero, J.J.; Urreta, J.; García, R.; Frías, M. Aging and durability of ternary cements containing fly ash and activated paper sludge. Constr. Build. Mater. 2014, 52, 253-260. [CrossRef]

11. Frías, M.; Vigil, R.; García, R.; de Soto, I.; Medina, C.; Sánchez de Rojas, M.I. Scientific and technical aspects of blended cement matrices containing activated slate wastes. Cem. Concr. Compos. 2014, 48, 19-25. [CrossRef]

12. Goñi, S.; Frías, M.; Vigil, R.; Vegas, I. Decalcification of activated paper sludge-fly ash Portland cement blended pastes in pure water. Cem. Concr. Comp. 2013, 40,1-6. [CrossRef]

13. Nakanishi, E.; Frías, M.; Santos, S.F.; Rodrigues, M.S.; Vigil, R.; Rodriguez, O.; Savastano, H. Investigating the posible usage of elephant grass ash to manufacture the eco-friendly binary cements. J. Clean. Prod. 2016, 116, 236-243. [CrossRef]

14. Younsi, A.; Turcy, P.; Ait-Mokhtar, A.; Staquet, S. Accelerated carbonation of concrete with high content of mineral additions: Effect of interactions between hydration and drying. Cem. Concr. Res. 2013, 43, 25-33. [CrossRef]

15. Groves, G.W.; Brough, A.; Richardson, I.G.; Dobsont, C.M. Progressive changes in the structure of hardened C3S cement pastes due to carbonation. J. Am. Ceram. Soc. 1991, 74, 2891-2896. [CrossRef]

16. Black, L.; Breen, C.; Yarwood, J. Structural features of CSH (I) and its carbonation in air-A Raman spectroscopy study. Part II: Carbonated phases. J. Am. Ceram. Soc. 2007, 90, 908-917. [CrossRef]

17. Martínez, S.; Fernández, L. Carbonation of ternary cement systems. Constr. Build. Mater. 2012, 27, $313-318$. [CrossRef]

18. Tonoli, G.H.D.; Pizzol, V.D.; Urrea, G.; Santos, S.F.; Mendes, L.M.; Santos, V.; John, V.M.; Frías, M.; Savastano, H. Rationalizing the impact of aging on fiber matrix interfase and stability of cement based composites submitted to carbonation at early ages. J. Mater. Sci. 2016, 51, 7929-7943. [CrossRef]

19. Kurdowski, W. Cement and Concrete Chemistry; Springer: London, UK, 2014.

20. Castellote, M.; Fernández, L.; Andrade, C.; Alonso, M.C. Chemical changes and phase analysis of OPC pastes carbonated at different CO2 concentrations. Mater. Struct. 2009, 42, 515-525. [CrossRef]

21. Arandigoyen, M.; Bicer-Simsir, B.; Alvarez, J.I.; Lange, D.A. Variation of microstructure with carbonation in lime and blended pastes. Appl. Surf. Sci. 2006, 252, 7562-7571. [CrossRef]

22. Goñi, S.; Gaztañaga, M.T.; Guerrero, A. Role of cement type on carbonation attack. J. Mater. Res. 2002, 17, 1834-1842. [CrossRef]

23. Xu, A.; Chandra, S.; Rodhhe, M. Influence of alkali on carbonation of concrete. In Third CANMET/ACI International Conference on Durability of Concrete; Malhotra, V.M., Ed.; CANMET / ACI: Nice, France, 1994.

24. Frías, M.; Vigil de la Villa, R.; Sánchez de Rojas, M.I.; Medina, C.; Valdés, A.J. Scientific aspects of kaolinite coal mining wastes in pozzolan $/ \mathrm{Ca}(\mathrm{OH})_{2}$ system. J. Am. Ceram. Soc. 2012, 95, 386-391. [CrossRef]

25. Frías, M.; Sánchez de Rojas, M.I.; García, R.; Valdés, A.J.; Medina, C. Effect of activated coal mining wastes on the properties of blended cement. Cem. Concr. Compos. 2012, 34, 678-683. [CrossRef]

26. Frías, M.; Rodriguez, O.; Vigil de la Villa, R.; García, R.; Martínez-Ramírez, S.; Fernández-Carrasco, L.; Vegas, I. The influence of activated coal mining wastes on the mineralogy of blended cement pastes. J. Am. Ceram. Soc. 2016, 99, 300-307. [CrossRef]

27. Vigil de la Villa, R.; Frías, M.; García, R.; Martínez-Ramírez, S.; Fernández-Carrasco, L. Chemical and mineral transformations that occur in mine waste and washery rejects during pre-utilization calcination. Int. J. Coal Geol. 2014, 132, 123-130. [CrossRef]

28. García, R.; Vigil de la Villa, R.; Frías, M.; Rodríguez, O.; Martínez-Ramírez, S.; Fernández-Carrasco, L.; de Soto, I.S.; Villar, E. Mineralogical study of calcined coal waste in a pozzolan/Ca(OH) 2 system. Appl. Clay Sci. 2015, 108, 45-54. [CrossRef]

29. García, R.; Vigil de la Villa, R.; Rubio, V.; Frías, M. The transformation of coal mining waste minerals in the pozzolanic reaction of cements. Minerals 2016, 6, 64. [CrossRef]

30. Yague, S.; Sánchez, I.; Vigil de la Villa, R.; García, R.; Zapardial, A.; Frías, M. Coal mining tailings as a pozzolanic material in cements industry. Minerals 2018, 8, 46. [CrossRef]

31. European Commission for Standardization. Cement Part 1: Compositions, Specifications and Conformity Criteria for Common Cement; UNE EN 197-1; Asociacion Espanola de Normalizacion: Madrid, Spain, 2011. 
32. Frías, M.; Sánchez de Rojas, M.I.; Medina, C.; Villar, E. New trends for nonconventional cement-based materials: Industrial and agricultural waste. In Sustainable and Nonconventional Contruction Materials Using Inorganic Bonded Fiber Composites; Savstano, H., Fiorelli, J., dos Santos, S.F., Eds.; Woodhead Publishing: Duxford, UK, 2017; pp. 165-184.

33. Spanish Standard Institution. Métodos de ensayo de cementos. Determinación Cuantitativa De Los Componentes; UNE 80216-2010; Asociacion Espanola de Normalizacion: Madrid, Spain, 2010. (In Spanish)

34. Koch, A.; Steinegeer, H. A raspid method for testing the ressitance of cements to sulphate attack. Zem. KalK Gips 1960, 13, 317-324.

35. Spanish Standard Institution. Corrosión En Armaduras: Determinación De La Profundidad De Carbonatación En Hormigones Endurecidos y Puestos En Servicio; UNE 112-011-94; Asociacion Espanola de Normalizacion: Madrid, Spain, 1994. (In Spanish)

36. Rietveld, H.M. A profile refinement method for nuclear and magnetic structures. J. Appl. Crystallogr. 1969, 2, 65-71. [CrossRef]

37. Ruan, C.D.; Ward, C.R. Quantitative X-ray powder diffraction analysis of clay minerals in Australian coals using Rietveld methods. Appl. Clay Sci. 2002, 21, 227-240. [CrossRef]

38. Bai, J.; Wild, S.; Sabir, B.B. Sorptivity and strength of air cured and water cured PC-PFA-MK concrete and sthe influence of binder composition on carbonation depth. Cem. Concr. Res. 2002, 32, 1813-1821. [CrossRef]

39. Sisomphon, K.; Franke, L. Carbonation rates of concretes containing high volume of pozzolanic materials. Cem. Concr. Res. 2007, 37, 1647-1653. [CrossRef]

40. Frías, M.; Goñi, S. Accelerated carbonation effect on behaviour of ternary portland cements. Compos. Part B Eng. 2013, 48, 122-128. [CrossRef]

41. Van Balen, K.; Van Gemert, D. Modelling lime mortar carbonation. Mater. Struct. 1994, 27, $393-398$. [CrossRef]

42. Taylor, H.F.W. Cement Chemistry, 2nd ed.; Thomas Telford Publishing: London, UK, 1997.

43. Pizzol, V.D.; Mendes, L.M.; Savastano, H.; Frías, M.; Davila, F.J.; Cobcotto, M.A.; John, V.M.; Tonoli, G.H.D. Mineralogical and microstructural changes promoted by accelerated carbonation and ageing cycles of hybrid fiber cement composites. Constr. Build. Mater. 2014, 68, 750-756. [CrossRef]

44. Fernández, M.; Simons, S.J.R.; Hills, C.D.; Carey, P.J. A review of accelerated carbonation technology in the treatment of cement-based materials and sequestration of $\mathrm{CO}_{2}$. J. Hazard. Mater. 2004, 112, 193-205. [CrossRef] [PubMed]

45. Ngala, V.T.; Page, C.L. Effects of carbonation on pore structure and diffusional properties of hydration cement pastes. Cem. Concr. Res. 1997, 27, 995-1007. [CrossRef]

46. Puertas, F.; Goñi, S.; Hernández, M.S.; Varga, C.; Guerrero, A. Comparative study of accelerated decalcification process among C3S, grey and white cement pastes. Cem. Concr. Compos. 2012, 34, 384-391. [CrossRef]

(C) 2018 by the authors. Licensee MDPI, Basel, Switzerland. This article is an open access article distributed under the terms and conditions of the Creative Commons Attribution (CC BY) license (http:/ / creativecommons.org/licenses/by/4.0/). 